\title{
Leadership Lessons from Bhagavad Gita
}

USHA SUNDARI and KARANAM N. RAO

\begin{abstract}
There has been a flurry of activity in management literature for developing management theories for the last one and half century. People, in general, tend to assume that globally renowned companies adopt the best managerial practices and the management theories of the West are the best worthy of emulation by the Eastern counterparts. In the backdrop of crumbling communist concepts and the near failure of capitalistic models, especially after the fall of Lehman Brothers in USA, scholars have begun to perceive the hollowness of those models and turned their attention to the ancient wisdom of oriental countries. Leadership is having greater significance in managing an organization. Leaders are the persons who motivate and build the morale of the followers in achieving organizational goals to newer heights. Notwithstanding the prevalence of plethora of literature on leadership from the Western management perspective, scholars have begun to take a relook at ancient Indian scriptures which have valuable lessons in the area of leadership. In Bhagavad Gita, Lord Krishna acted as a role model and imparted great lessons of leadership to Arjuna. An attempt is made in this article to draw leadership lessons from Gita which inspired the people from time immemorial.
\end{abstract}

Key words: Managerial Practices, Leadership and Gita.

The entrepreneurial success in any organization is to large extent depends on the leadership qualities of the entrepreneur. There are umpteen number of leadership theories drawn from western perspective. The lessons of leadership are, however imbedded in traditional scriptures like srutis (revelation like Vedas) and smritis (traditional texts like Manu Smriti, Parasara Smriti etc). These are largely ignored by the populace perceiving them to be religious documents which, if taught, may impinge our secular credentials. But these scriptures are not meant for any religion and they are storage of valuable knowledge. The objective of this paper is to draw inferences on leadership from the celestial book, Bhagavad Gita (Gita).

\section{METHODOLOGY}

The methodology largely exploratory trying to unearth leadership values imbedded in Gita which are imparted by Lord Krishna to Arjuna. Good leaders are made not born. If one has the desire and willpower, one can become an effective leader. Good leaders develop through a never ending process of self-study, education, training, and experience (Jago, 1982). Good leaders are continually working and studying to improve their leadership skills; Leaders carry out this process by applying their leadership knowledge and skills. Knowledge and skills contribute directly to the process of leadership, while the other attributes give the leader certain characteristics that make him or her unique. (Jago, 1982).

Character, Personality and Leadership, though interconnected have different connotations. Character is the sum total of a person's inner qualities. If character is a flower, personality is its fragrance. Character and personality, when attuned to inspire others result in Leadership.

Leadership is most important for any project to be guided, steered and completed with a 
success with in a given time. Time management is important that many more projects could be accomplished effectively. That has been the target of all managers, however they are placed. They attract work and get the satisfaction of getting the work done for certain. Although one knows the planning, mode in itself, and details for execution, still an elder's counsel is a factor of relevance and conditional.

Vedas, Puranas, Epics and many such sources have provided big sets of lessons under the canopy of context, need and urgency. Sacrifice is a great need postulated as basic lesson for leadership. The same has been variously explained in the literature. There are good managers and leaders who spent a great deal of thought and practically demonstrated. They have become famous and gurus to the posterior times Lord Krishna is a grand example.

The literature review revealed that most of the authors' contribution to 'leadership' is generic in nature as far as the study is focused to leadership styles in general. In order to understand Eastern perspectives, it is imperative to read original scriptures apart from commentaries available from a host of data bases like Ebsco, Proquest, Springerlink and the like to the topic of discussion.

While understanding the concepts of Gita, most of the existing research broadly attempted to interpret the theories drawn from translations of the text from the Indian and foreign authors. Not much is done to read the original text of Gita for drawing leadership lessons. This research gap is sought to be plugged by meaningful study of the original text of Gita and popular commentary of Sankara.

\section{Bhagavad Gita \& Leadership}

Plethora of contemporary leadership topics such as emotional intelligence, situational leadership, character and integrity were discussed at length in the Bhagavad Gita thousands of years ago. These topics were discussed in a philosophical context, as management science as we know today did not exist then. In fact, Shankara in his commentary on Gita says that the Gita is meant to strengthen the ruling community in order to ensure effective way of leadership. The famous words run like this: "Jagatpalayitroonaam khatriyaanam balaadhaanaaya" (Shankara, 2007). Much before Taylor defined 'work and worker', and Drucker defined 'knowledge and knowledge worker', the topics of work and knowledge were elaborately discussed in the Bhagavad Gita. Taylor (1918) in his book 'Principles of Scientific Management' laid down the fundamental principles of large-scale manufacturing through assembly-line factories. He emphasized gaining maximum efficiency from both machine and worker, and maximization of profit for the benefit of both workers and management. The term 'knowledge worker' was used by Drucker (1959) in his book 'Landmarks of Tomorrow'. A knowledge worker is anyone who works for a living at the tasks of developing or using knowledge.

Western management model revolves around materialistic pursuits and engender dichotomy in life. Men at the work place view their profession as a means of livelihood and they look for fulfillment of life outside their profession. It is an undisputed fact that if productivity of an industry has to improve, the productivity of the men associated with the industry has to improve. Even the latest technology or modern methods of management cannot achieve greater productivity unless the workers, executives, and administrators improve their own efficiency and productivity. Personality rehabilitation is the method to make people more dynamic, creative, and selfactualized. The manager should first learn to control and understand himself. A practitioner of sama (restraint or control of the mind), dama (restraint over the five organs of perception), titiksha (forbearance) and uparama (carrying out your svadharma and renounce self) will easily 
attain Citta Suddhi (purity of mind) and Citta ekagratha (single pointedness of intellect) which are essential for holistic human personality (Vidhu \& Rao, 2012).

The doctrine of Bhagavad Gita was given to mankind by Lord Krishna in the battle of Mahabharata between Pandava and Kaurava Kings. Bhagavad Gita is all about dharma (righteousness) and re-establishment of dharma against all evil forces of adharma (lawlessness). Lord Krishna admonished Arjuna not to behave like a coward and fight like a king who had interest of his countrymen before self. He gave a clarion call to rise above 'hrudaya daurbalyam' (weakness of the heart) and asked Arjuna to get up and fight for a righteous cause (Bhagavad Gita, $2 / 3)$.

Bhagavada Gita is a remarkable book to derive many lessons for the personality features of a good and able leader. Here we see great people come in dialogue to impart the lessons to proceed in the leadership modes. In Mahabharata, there are four important texts and all of them provide lessons of leadership: (i) Bhagavad Gita, (ii) Vishnu Sahasranama, (iii) Viduraniti and (iv) Sanatsujatiyam. Here researchers focus is on Bhagavad Gita which is one of the four ratnas (jewels) of Mahabaharata. In this paper researcher have seen Yogesvaresvara (Lord Krishna) on toe to initiate and instill the spirit of management \& leadership.

In the length of eighteen chapters of the text, the Instructor Lord Krishna teaches Yogas (Lokesmin dvidha nishta, Bhagavad Gita, 3/3). These go into the division of Karma (action, activity and practical execution of the lessons to bring out necessary effect), and the Jnana (the power of knowledge and application). Karma yoga is meant to transcend the limits of performing actions for selfish good (kamya karma) to attain the goal of universal good (nishkama karma). Karma yoga is the preparatory state for attaining
Jnana yoga. Basically both the methods are meant to attain purity of mind and perform actions for common good of the community (loka sangraha).

\section{Leadership Lessons}

Bhagavad Gita lays emphasis on leadership based on morality. The central theme of Gita is about doing work in the most efficient manner without aspiring for fruit of action and also doing the work for common good. It advocates to look upon all living and non-living beings with equanimity and perceive everything from the perspective of supreme Brahman (Bhagavad Gita, 5/18). Lord Krishna also proclaims that developing a sense of equanimity begets a composed and completed personality (samatvam yoga vucyate), which is the quintessential attribute of a leader. Hee (2007) says that the Gita's advice can be useful in five areas of modern business. He suggests that the Gita provides advice on mission and core values, the development of new capabilities, the importance of developing business connections and communication, and the duty of managers to maintain a purpose centric perspective.

When Arjuna for the first time questioned his own actions and quest for power and glory, Krishna explained to him that each position, including that of soldier has a role to play in the cosmos. Leaders must be aware of that role and be prepared to rise and respond to the occasion by fulfilling the responsibilities imposed on them by their position. As stated in the Gita, perfection is attained when each attends diligently to his duty (Bhagavad Gita, 18/45). Leaders have a duty to effectively influence those whom they lead. It may be achieved by using many different approaches. The leader must uphold and maintain his / her upmost moral values while performing the said duties. The wise man who has conquered his mind and is absorbed in the Self is a lamp which does not flicker, since it stands sheltered from every will (Bhagavad Gita, 6/19). Being true to oneself 
and one's values is an essential aspect of leadership according to the Gita. Equally important is acting in a manner that one wishes to have emulated throughout the organization. For whatever a great man does, others imitate. People conform to the standard which he has set (Bhagavad Gita, 3/21). The leader must be a good role model and express the values of the organization through his/her behavior. Those Leaders who simply profess one set of values and do not act accordingly are not acting in accordance with the Bhagavad Gita.

Bhagavad Gita teaches that proactive behavior is superior to reactionary behavior. No man can attain freedom from activity by refraining from action; nor can one reach perfection by merely refusing to action. (Bhagavad Gita, 3/4). Arjuna was faced with a daunting task before him, one not of his making. Lord Krishna insisted that he (Arjuna) fulfills his responsibilities by taking aggressive action which was appropriate in the given situation. Inaction was ruled out as it would lead to failure. Krishna advised Arjuna to use his wisdom and be proactive. Only the unenlightened speak of wisdom and right action as separate, not the wise (Bhagavad Gita, 5/4). According to Gita, Lord Krishna advises Arjuna to combine his inner wisdom with the right actions. Wisdom, combined with right action is essential for good leadership. To lack either one produces poor results. Harmful events happen in the following two situations. i.e. (i) when a leader is unwise and (ii) when a leader is wise but, fails to act. The Gita teaches leaders that they will be forced from time to time to make difficult decisions, and that they must use their inner wisdom to guide them in making the correct decision. The Gita also implies that wisdom is a necessary precondition for the selection of good leaders. While training and development are important to organizational success, leadership qualities are viewed as being more innate and developed through introspection and meditation.
Bhagavad Gita makes several references to the importance of self-sacrifice and working for the benefit of the greater good. In many cases leaders must sacrifice their own interests in order to promote the well-being of the group they are leading. In the Bhagavad Gita, leaders act in the role of servant, not inconsistent with the servant leadership model popular in the West (Greenleaf, 2002). By sacrificing their own interests for the interests of the group, managers are able to better achieve their purposes. One can learn in the Gita that a good leader is one who is incapable of hatred towards any human being, who is kind and compassionate, free from selfishness, without pride, equable in pleasure and in pain, and is forgiving (Bhagavad Gita, 12/13). According to Gita tradition a humanistic leader is one who, is selfless and makes the wellbeing of his followers as the utmost priority. Good leaders are those who are filled with a positive energy, compassion and kindness towards others. Likewise in the Gita one can learn harmlessness, forgiveness, fortitude, purity, freedom instead of hate and vanity; these are the godly qualities. Hypocrisy, pride, insolence, cruelty, ignorance belong to one who is born of the godless qualities (Bhagavad Gita, 16/2). The actions of a good leader should be always beneficial to those whom one lead. The leader according to Gita should be above material gain and greed. When a man dwells on the objects of sense, one creates an attraction for them; attraction develops into desire, and desire breeds anger. Anger induces delusion; delusion, loss of memory; through loss of memory, reason is shattered; and loss of reason leads to destruction (Bhagavad Gita, 2/62-63). Krishna tells Arjuna to just perform his duty with utmost sincerity and not worry of the outcome. According to Gita dwelling on material gains in leadership role does not lead to a state/sense of consciousness. The gates of hell are three - lust, 
wrath, and avarice (greed). They destroy the self, it should be avoid (Bhagavad Gita, 16/21). Leaders must be aware and mindful of their motives both good and bad, and their effects on those whom they lead. The purpose of the leader is to serve one followers in helping them to attain a higher level of performance and perfection at whatever they do in accordance with dharma.

In order to know others, the leader should know one self. This understanding is not confined to physical, psychological and emotional behavior. The leader should go to the deeper level of consciousness. Through the regular practice of meditation one can go the deeper level of consciousness. In Bhagavad Gita, Lord Krishna says that regular practice of meditation one can understand his true potential and purpose of life. With this understanding one can guide his followers in a better way (Roka, 2006).

In order to be effective the leaders should have good communication skills. Lord Krishna says that the leader should communicate honestly and respect towards others. With their inspirational speech leaders motivate their followers and lead them towards organizational objectives. Leaders like Mahatma Gandhi, Dr. King and Kennedy became known as effective leaders mainly because they communicated elegantly at all times. In the business world, one knows that leaders like Jack Welch, Andy Groves and John Chambers as great communicators. When these leaders communicated to their followers, they were always consistent on the vision and goals they presented to their organizations (Roka, 2006).

\section{Growing Resilience}

Never was good work done without much trouble. Leaders are tough or die-hard, and they are climbers they persist (Stoltz, 1997). They keep on climbing in spite of obstacles. In the Gita, it is said that one should learn to be neither an agitator nor agitated by the world and to accept the knocks of life as blessings in disguise. One strengthens oneself. When one learns to take shelter in the beyond or the universe, one experiences great peace of mind and comfort, which displaces all negativity and pain (Cheng \& Low, 2011).

Krishna always supported Arjuna, but never controlled him. He only advised and guided Arjuna. True leaders enable their followers to build selfconfidence. They provide necessary guidance and mentoring till their followers are able to handle their own affairs. By making them independent the leader draws them towards oneself.

When Arjuna entered the battlefield, and realized that he had to fight with his own kith and kin, he was overcome with grief. Seeing Arjuna's anguish Krishna counseled and advised him to do his duty. Using philosophical concepts, Krishna explained the nature of his duty in the present context and cleared Arjuna confusion.

\section{Conclusion}

Bhagavad Gita is a source of inspiration for humanity. It is not a religious book for a specific community. The unwise people attribute Gita as a Hindu scripture but they are unaware that the word 'Hindu' is not even mentioned once in Gita. Developing good sense of neutrality is an important prerequisite for discharging one's work very effectively. It requires deep contemplation of this idea and a conviction of its usefulness. Embracing karma yoga is a panacea for improving the quality of leadership in organizations. This leads to look upon work/ action as an offering to the God and the burden of work suddenly becomes light.

USHA JAISWAL, MBA, Assistant Professor, School of Yoga and Health, Dev Sanskriti Vishwavidyalaya, Haridwar; KARANAM N. RAO, PhD, Assistant Professor, School of Business, Alliance University, Bangalore, India. 


\section{SUNDARI \& RAO}

\section{REFERENCES}

Cheng, K. \& Low, P. (2011). The fundamental leadership wisdom of the bhagavad gita. Business Journal of Entrepreneurs, 01, 90-100.

Drucker, P. (1957). Landmarks of Tomorrow (p.122). New York: Harper \& Row.

Greenleaf, R. (2002). Servant leadership: A journey into the nature of legitimate power (p.6). Mahwah, NJ: Paulist Press.

Hee, C. (2007). A holistic approach to business management: Perspectives from the bhagavad Gita. Singapore Management Review, 29(1), 73-84.

Jago, A. G. (1982). Leadership: Perspectives in theory and research. Management Science, 28(3), 315-336.

Roka, P. (2006). Bhagavad Gita on effective Leadership: Timeless wisdom for Leaders (p. 60, 66). New Delhi: Jain Book Agency.

Shankara, A. (2007). Bhagavad Gita Bhashya (SanskritEnglish Commentary by A. G. Krishna Warrior, 2007, p. 60-70). Madras: Sri Ramakrishna Math.

Stoltz, P. G. (1997). Adversity Quotient Turning Obstacles into Opportunities (p.28). New York: John Wiley \& Sons.

Taylor, F. W. (1918). Principles of Scientific Management. London: Routledge Publication.

Vidhu, G. \& Rao, K. (2012). Vedanta and the Art of Successful Management (p. 475-484). New Delhi: Vedic Foundations of Indian Management.

Advesta sarva-bhutanam maitrah karuna eva ca nirmamo nirahankarah sama-duhkha-sukhah ksami (Bhagavad Gita, 12/13) ॥

Ahimsa satyam akrodhas tyagah santir apaisunam daya bhutesv aloluptvam mardavam hrir acapalam (Bhagavad Gita, 16/2) II
Dhyayato visayan pumsah sangas tesupajayate sangat sanjayate kamah kamat krodho bhijayate// Krodadbhavati sammohah sammoha smriti vibhrama smtir bhramsho buddhi nasha buddhi nashatpranashyati (Bhagavad Gita, 2/62-63) ॥ Klaibyam ma sma gamah partha naitat tvayy upapadyate ksudram hrdaya-daurbalyam tyaktvottistha parantapa (Bhagavad Gita, 2/3) ॥

Loke 'smin dvi-vidha nistha pura prokta mayanagha jnanayogena sankhyanam karma-yogena yoginam (Bhagavad Gita, 3/3) II

Na karmanamanarambhat naiskarmyam purusosnute na cha samnyasanadeva siddhim samadhigacchati (Bhagavad Gita, 3/4) II

Sankhya-yogau prithag balah pravadanti na panditah ekam apy asthitah samyag ubhayor vindate phalam (Bhagavad Gita, 5/4) II

Sve sve karmanya abhirata: samsiddhim labhate nara (Bhagavad Gita, 18/45) ॥

Trividham narakasyedam dvaram nasanam atmanah kamah krodhas tatha lobhas tasmad etat trayam tyajet (Bhagavad Gita,16/21) ॥

Vidya-vinaya-sampanne brahmane gavi hastini suni caiva svapake ca panditah sama-darsinah (Bhagavad Gita, 5/18) II

Yad yad acarati sresthas tat tad evetaro janah sa yat pramanam kurute lokas tad anuvartate (Bhagavad Gita, 3/21) II

Yatha deepo nivathastho nengathe sopamasmrutha yogino yatha chittasya yunjatho yagam atmanah (Bhagavad Gita, 6/19) ॥ 